\title{
Analysis of Nurses Staff Needs Using Workload Indicate Staff Need in Pediatric Ward with Time Motion Study
}

\author{
Richa Noprianty $^{1}$, Syafitri Anisa Febianti ${ }^{2}$ Jahidul Fikri $^{3}$ \\ ${ }^{1}$ Correspondence Author: richa.noprianty@gmail.com \\ 1 Universitas Bhakti Kencana Bandung, Indonesia \\ ${ }^{2}$ College of Health Sciences Dharma Husada Bandung, Indonesia \\ ${ }^{3}$ College of Health Sciences Dharma Husada Bandung, Indonesia
}

\section{N D E X I N G}

\section{Keywords:}

Nursing workload;

Time and motion

study;

WISN;

Direct care;

Indirect care; \begin{abstract}
A B S T R AC T
Hospital "X" has implemented the WISN calculation method in determining the need for nurses in the Inpatient Room, but this calculation is applied to all inpatients room with the method work sampling, while calculating the need for nurses based on the WISN Method can also use the time and motion study method. The purpose of this study was to determine the analysis of the needs of nurses based on the WISN method. The method was descriptive observational with One-Shot method. The number of samples was 9 nurses when taking action directly, indirectly and personally both of so obtain 27 times of observations, with a total 12,960 minutes. Observations were done using time and motion study with 5 steps. The results showed that the morning shift was obtained the results of direct activities were 609.35 , indirect activities were 1783.13 , and personally were 386.23 , while evening shift was obtained the results of direct activities were 1119.26 , indirect activities were 1413.46 , and personally were 466.18 , and night was obtained the results of direct activities were 700.1, indirect activities were 1541.7 , and personally were 2126.22 , with total workload standards 422773.6674 hours/years. The final results obtained the need for nurses is 28 people, while which are available is 24 nurses, with the WISN Ratio result, it is found that 0.8 is less than 1 . The results of this study can be taken into consideration in reducing the number of nursing staff in the morning shift and added the afternoon shift.
\end{abstract}

Rumah Sakit " $X$ " sudah menerapkan perhitungan metode WISN dalam menentukan kebutuhan tenaga perawat di Ruang Rawat Inap, akan tetapi perhitungan ini diberlakukan untuk semua ruang rawat inap dengan metode yang digunakan yaitu work sampling, sedangkan menghitung kebutuhan tenaga perawat berdasarkan Metode WISN dapat juga menggunakan metode time and motion study. Tujuan dari penelitian ini adalah untuk mengetahui analisa kebutuhan tenaga perawat berdasarkan metode WISN. Metode pada penelitian ini adalah metode deskriptif observasional dengan model pendekatan One-Shot metod. Jumlah sampel sebanyak 9 perawat ruangan saat melakukan tindakan keperawatan secara langsung, keperawatan tidak langsung dan pribadi, baik pada shift pagi, sore dan malam sehingga didapatkan jumlah 27 kali pengamatan dengan total menit 12.960 menit. Pengamatan dilakukan dengan cara time and motion study dengan 5 langkah. Dari hasil penelitian menujukan bahwa pada shift pagi didapatkan hasil kegiatan langsung sebanyak 609.35, tidak langsung sebanyak 1783.13, dan pribadi sebanyak 386.23, sedangkan shift sore didapatkan hasil kegiatan langsung sebanyak 1119.26, tidak langsung sebanyak 1413.46, dan pribadi sebanyak 466.18, dan sedangkan shift malam didapatkan hasil kegiatan langsung sebanyak 700.1, tidak langsung sebanyak 1541.7, dan pribadi sebanyak 2126.22, dengan jumlah Standar beban kerja 422773.6674 jam/tahun, standar kelonggaran 0.023775782, sehingga didapatkan hasil akhir jumlah Kebutuhan tenaga keperawatan sebanyak 28 orang, sedangkan yang tersedia 24 orang. Hasil WISN Rasio didapatkan bahwa 0,8 kurang dari 1. Dapat disimpulkan bahwa terjadi kekurangan tenaga keperawatan. Hasil penelitian ini dapat dijadikan bahan pertimbangan dalam mengurangi jumlah tenaga keperawatan pada shift pagi dan ditambahkan pada shift sore.

(C) 2020 JMMR. All rights reserved

Article History: Received 2019-10-17; Revised 2019-12-20; Accepted 2020-03-23 


\section{INTRODUCTION}

Calculating the proportion of nurses in a hospital must consider several aspects that can affect the needs of nurse's employment in a hospital. Among them are data on the number of patient visits, the level of dependence of patients during treatment, actions taken by nurses both direct nursing treatments, indirect nursing treatments, and personal nursing, BOR and LOS in the room for 6 months - 1 year. Several methods are used to calculate the number of nurses needed, including: Douglas Method, Ratio Method, Gillies Method, PPNI Workshop Method, MOH Method, Ilyas Method, and WISN Method (Nursalam, 2015). Of the several methods of calculating nurses need, the closest result to the reality of the nurses capacity needs is by calculating the nurse's workload in the room with the standards activity that applied to each component of the task (Kementrian Kesehatan Republik Indonesia, 2010).

Nurse workload is all activities carried out by nurses based on calculations and experience in a certain time unit (Noprianty, 2013). Nurses workload analysis can be view from aspects such as tasks that carried out based on the main functions and additional tasks performed, number of patients to be treated, work capacity according to education obtained, work time used to do their work according to work hours that takes place every day, and the overall facilities that can help nurses complete their work well (Marquis \& Huston, 2010).

"X" Hospital calculates the need for nurses using the Gillies method but discontinued because it is not appropriate. Furthermore, the "X" Hospital used the Ministry of Health and PPNI methods; in 2006 it changed to the Ilyas method and changed again in 2015 until now 2019 using the WISN method. The method used in the "X" Hospital is the Work Sampling Method where thousands of observations of activities will be obtained from a number of personnel observed.

Inpatient rooms that have a high BOR $(85.60 \%)$, a drastic increase in the number of patients with a difference of 57 from the previous month is the Pediatric Ward with the most number of beds totaling 43 beds which are included with isolation rooms and neonatus, and has 21 nurses with an career path of PK III 2 people, PK II 5 people, and PK I 14 people.

Based on the results of interviews with the head of the room, he said that in the last 1 year several nurses contracted labor resigned, so the workload of nurses in the room is increasing due to the number of nurses decreasing while the number of patients is increasing. This finds is reinforced by the data obtained from the implement nurses, the executive nurses feel that the burden of work in the room is indeed very high, so the implementing nurses say they often feel tired and lack enthusiasm when going to work. This condition is the basis reason of this research to analyze the needs of nurses based on the WISN method with the Time and Motion Study approach in the Pediatric Ward of the "X" Hospital.

\section{RESEARCH METHOD}

This research is an observational descriptive study using the time and motion study observation method and the one-shot method approach that aims to determine the analysis of the needs of nurses based on the WISN method. The study was conducted in the Pediatric Ward of the "X" Hospital. This study samples were all of the nurses who fulfilled the sample criteria of 9 nurses. Data collection was divided into primary data collected through direct observation of the activities carried out by nurses during working hours and secondary data 
such as available work time, BOR and nurse shift schedules obtained through interviews with nursing departments and hospital documents. The nursing staffs were observed as many as 9 people. This research has been conducted ethics feasibility test No. 02 / KEPK / PE / IX / 2019.

There are sources from journals that state that WISN calculations use 8 steps, namely : 1) Determining priority cadre(s) and health facility type(s), Estimating available working time, 3) Defining workload components, 4) Setting activity standards, 5) Establishing standard workloads, 6) Calculating allowance factors, 7) Health service activities, and 8) The WISN results are analyzed in two ways: difference and ratio (Samsuzzaman, 2013). But the research using The steps for calculating power requirements based on the WISN method include 5 steps, namely:

1. determine available working time based on working days, annual leave, education and training, national holidays and annual leave, work absence and nurse's working time for one year;

2. determine the work units and HR categories that are counted;

3. developing workload standards;

4. arrange leeway standards;

5. Calculate the need for nursing staff.

Observation of nurses is done at every shift both in the morning, evening and night shifts where each shift one nurse is observed. Each nurse was observed once, in the morning, evening and night shifts. Then it is entered into the formula for calculating the number of workers from the Workload Indicators of Staff Need (WISN).

The difference between the real number in the room and the results of HR standards according to WISN will appear less or more after calculating the reality and needs of HR with the formula:

WISN Ratio : Number of available nurses in room

Number of nurse according WISN

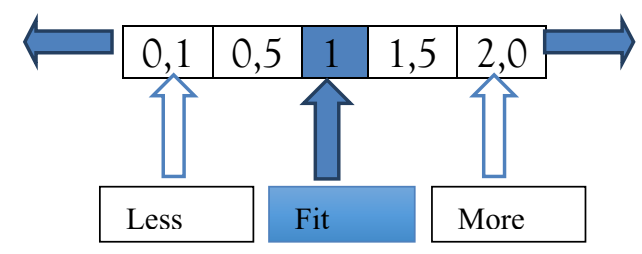

Figure. 1 WISN ratio standards

1. Available Working Time

\section{RESULT AND DISCUSSION}

Obtained data that needed to determine available working time:

a) Weekdays, according to applicable regulations in the workplace or local area Regulation (A)

b) Annual leave, in accordance with the regulations of each HR has the right to take 12 days off work every year (B) 
c) Education and training, in accordance with applicable regulations in the workplace to maintain and improve competence / professionalism in each category of HR has the right to attend training / courses / seminars / workshops in 4 working days (C).

d) National Holidays, based on the Joint Ministerial Decree on National Holidays and Joint Leave, on the year of 2019 stipulates 16 Working Days and 4 working days for joint leave (D).

e) Absence from work, according to data on average absence from work (for a period of 1 year) due to illness, not entering with or without notice / permission is 3 days (E).

f) Working time, in accordance with the regulations in the workplace or Regional Regulations, generally working time in 1 day is 8 hours $(F)$.

Table. 1 Available Nurse Work time in the Hospital

\begin{tabular}{|c|l|c|l|}
\hline Code & \multicolumn{1}{|c|}{ Factor } & $\begin{array}{c}\text { SDM Categories } \\
\text { Nurses }\end{array}$ & Information \\
\hline A & Work day & 300 & Day/Year \\
\hline B & Annual Leave & 12 & Day/Year \\
\hline C & Training / Education & 4 & Day/Year \\
\hline D & National Holiday & 4 & Day/Year \\
\hline E & Work Absence & 3 & Day/Year \\
\hline F & Working Time & 8 & Hour /Day \\
\hline & Available Working Time & 2.088 & Hour/Year \\
\hline & Available Working Time & 125.280 & Min/Year \\
\hline
\end{tabular}

Obtained amount of work time available is:

Available Working Time $=\{\mathrm{A}-(\mathrm{B}+\mathrm{C}+\mathrm{D})\} \times \mathrm{E}$

$$
\begin{aligned}
& =\{300-(12+4+20+3)\} \times 8 \\
& =2.088 \text { Hour/Year } \\
& =125.280 \text { Minute/Year }
\end{aligned}
$$

So, the work time needed by each nurse is 125,280 minutes / year.

The working time available at Bandung's "X" Hospital is still fewer than the sum of work time nursing staff at Kendari City Hospital at 128,160 minutes per year. This is differences is due in the determination of annual leave of 8 days / year, national holidays (none), absence from work for 21 days / year from each nursing staff in force at each hospital (Sitti Nurjanah, Ambo Sakka, 2017).

2. Establish Work Units and HR Categories

The work unit in calculating the need for nurses in this study is the Pediatric Ward selection of work sub-units based on the highest number of patient visits, namely the Pediatric Ward.

3. Develop Workload Standards

Formula Used

Workload Standards $=$ Available Working Time

Average time of main activity 
The results table 1 . Showed that the standard nursing workload in the Pediatric Ward of the "X" Hospital for direct action amounted to 407615.9562 hours / year and for indirect actions amounted to 15157.71124 hours / year, which if added by direct and indirect actions amounted to 422773.6674 hours /year.

In accordance with research that shows that the standard workload for direct nursing activities is 129.66 hours and indirect nursing actions are 72.75 hours. While for productive nursing actions with a total of 237864.96 (Ni Luh Ade Kusuma Ernawati, Nursalam, 2011).

According to Gillies theory, direct treatment for patients is $4-5$ hours / client / day, indirect patient care hours are 1 hour / client / day, and health counseling is 0.25 hours / client / day. Nurses must maximize direct treatment time to patients so that nursing services can run optimally (Gillies, 1996). Direct nursing activities are nursing service activities that are directly related to patients in order to meet bio-psychosocial-spiritual needs in accordance with nursing service standards. Direct care measures can increase nurses caring behavior for patients. That way can improve the quality of quality nursing care. The more direct nursing actions take place, the more frequent interaction of nurses with patients (Rusell C. Swansburg, 2004), (Firmansyah et al., 2019).

Faye G. Abdellah explained that one of the things that could happen if the nurses' workload was overloaded was workplace accidents both for nurses and patients. This is confirmed from the study that the number of nurses who are not balanced with the patient causes the implementation of the patient falls to the patient is not optimal (Dewi \& Noprianty, 2018).

4. Establish Leeway Standards

Leeway Standard $=$ time per leeway factor

Available working time

The results table 2. Showed that the nurse Leeway standard in the "X" Hospital of Bandung was 0.023775782 . The results of this leeway standard differ from research at XY2 Hospital that the leeway standard is 0.034 (Julia et al., 2014). This is caused by the type of activity and the need for time to complete the nurse's personal activities (Cucu , Hesti Nuraeni, 2019).

Table.2 Nurse Leeway Work Factor

\begin{tabular}{|l|l|c|c|}
\hline NO & \multicolumn{1}{|c|}{ Non-productive activities } & Leeway Factor & Leeway Standards \\
\hline 1 & Pray time & 319.41 & 0.002549569 \\
\hline 2 & Eat and Drink & 604.95 & 0.004828784 \\
\hline 3 & Toilet & 84.74 & 0.000676405 \\
\hline 4 & Personal Telephone & 299.8 & 0.00239304 \\
\hline 5 & Change clothes & 49.73 & 0.000396951 \\
\hline 6 & Sleep & 1620 & 0.012931034 \\
\hline \multicolumn{2}{|c|}{ SUM } & 0.023775782 \\
\hline
\end{tabular}

5. Calculating Nurses' Needs

The results in this research of workload observation for The number of samples was 9 nurses when taking action directly, indirectly and personally both in the morning, evening 
and night shift number of so obtain 27 times of observations shows that the most time consuming nursing activity was indirect care of 4738.29 (46.7\%), direct care of $2428.7124 \%$ ) and nonproductive of 2978.63 (29.3\%). This can be used by indirect care nursing activities which require a lot of time and must be completed in accordance with the procedure in the inpatient ward.

Table. 3 The Calculation of the Number of Performer Nurses by WISN

\begin{tabular}{|c|c|c|c|c|}
\hline $\mathrm{NO}$ & Nursing Activities & Workload Standards & $\begin{array}{c}\text { Quantity of } \\
\text { principal } \\
\text { activities }\end{array}$ & Nurse Needs \\
\hline \multicolumn{5}{|c|}{ Direct Care } \\
\hline 1. & $\begin{array}{l}\text { Intravenous drug } \\
\text { administration }\end{array}$ & 267.5951043 & 496 & 1.853546616 \\
\hline 2. & Replace IV fluids & 1018.370997 & 496 & 0.487052363 \\
\hline 3. & put an IV & 479.5406699 & 496 & 1.034323116 \\
\hline 4. & Overcoming Congestion IV & 1496.774194 & 496 & 0.33137931 \\
\hline 5. & Releasing Infusion & 2179.161593 & 496 & 0.227610473 \\
\hline 6. & Check the Patient State & 358.9376271 & 496 & 1.381855683 \\
\hline 7. & Subcutaneous injection & 61112.19512 & 496 & 0.00811622 \\
\hline 8. & O2 therapy & 13751.92097 & 496 & 0.036067688 \\
\hline 9. & Nebulizer therapy & 886.5614606 & 496 & 0.559464879 \\
\hline 10. & TTV Checking & 444.7284345 & 496 & 1.115287356 \\
\hline 11. & OGT Installation & 28933.0254 & 496 & 0.01714304 \\
\hline 12. & Adjust patient position & 1436.862025 & 496 & 0.345196679 \\
\hline 13. & Giving Test Tubes to Patients & 83520 & 496 & 0.005938697 \\
\hline 14. & Repair the infusion pump & 1820.401046 & 496 & 0.272467433 \\
\hline 15. & Take a blood sample & 1592.677346 & 496 & 0.311425287 \\
\hline 16. & $\begin{array}{l}\text { Replacing Patient Infusion } \\
\text { Pump }\end{array}$ & 13706.78337 & 496 & 0.036186462 \\
\hline 17. & $\begin{array}{l}\text { Replacing the Syringe Pump } \\
\text { Liquid }\end{array}$ & 9895.734597 & 496 & 0.050122605 \\
\hline 18. & Bathing the Patient & 5725.776965 & 496 & 0.086625798 \\
\hline 19. & $\begin{array}{l}\text { Take the patient to the } \mathrm{OK} \\
\text { room }\end{array}$ & 7569.78852 & 496 & 0.065523627 \\
\hline 20. & Weigh the patient & 21342.41908 & 496 & 0.023240102 \\
\hline 21. & Do the anamnesa & 1298.103823 & 496 & 0.382095785 \\
\hline 22. & $\begin{array}{l}\text { Adjusting and Repairing in the } \\
\text { Incubator }\end{array}$ & 2581.495982 & 496 & 0.192136654 \\
\hline 23. & Provides Nutrition by NGT & 55680 & 496 & 0.008908046 \\
\hline 24. & Take the patient to move room & 5100.977199 & 496 & 0.097236271 \\
\hline 25. & $\begin{array}{l}\text { Take patient's family to the } \\
\text { emergency room }\end{array}$ & 4116.989813 & 496 & 0.120476373 \\
\hline 26. & Overcome Nosebleeds & 29757.71971 & 496 & 0.016667944 \\
\hline 27. & $\begin{array}{l}\text { administration of drugs } \\
\text { through NGT }\end{array}$ & 6111.219512 & 496 & 0.081162197 \\
\hline
\end{tabular}




\begin{tabular}{|c|c|c|c|c|}
\hline NO & Nursing Activities & Workload Standards & $\begin{array}{l}\text { Quantity of } \\
\text { principal } \\
\text { activities }\end{array}$ & Nurse Needs \\
\hline \multicolumn{5}{|c|}{ Direct Care } \\
\hline 28. & Transfusion & 2414.803392 & 496 & 0.205399745 \\
\hline 29. & Changing Patient Cloth & 22613.71841 & 496 & 0.021933589 \\
\hline 30. & Washout & 4245.340563 & 496 & 0.116833972 \\
\hline 31. & Go to Nutrition Installation & 8923.076923 & 496 & 0.055586207 \\
\hline 32. & Suction & 7233.256351 & 496 & 0.068572158 \\
\hline \multicolumn{5}{|c|}{ Indirect Care } \\
\hline 1. & accompany the doctor's visit & 298.9619377 & 496 & 1.659074074 \\
\hline 2. & $\begin{array}{l}\text { move the patient's prescription } \\
\text { medication notes to the } \\
\text { injection book }\end{array}$ & 563.6388177 & 496 & 0.879996169 \\
\hline 3. & $\begin{array}{l}\text { prepare tools and drugs for } \\
\text { injection }\end{array}$ & 207.1531326 & 496 & 2.394363985 \\
\hline 4. & accept new patients & 1621.327812 & 496 & 0.305922095 \\
\hline 5. & $\begin{array}{l}\text { communication to the patient's } \\
\text { family }\end{array}$ & 338.5488448 & 496 & 1.465076628 \\
\hline 6. & make service reports & 83.40656707 & 496 & 5.946773946 \\
\hline 7. & $\begin{array}{l}\text { handover of tasks during } \\
\text { changes of shift }\end{array}$ & 308.3359996 & 496 & 1.608634738 \\
\hline 8. & take calls from other rooms & 1089.865159 & 496 & 0.455102171 \\
\hline 9. & Washing Hands & 2146.675805 & 496 & 0.231054917 \\
\hline 10. & $\begin{array}{l}\text { discussion about the state of } \\
\text { the patient }\end{array}$ & 280.9535557 & 496 & 1.765416347 \\
\hline 11. & $\begin{array}{l}\text { Changing bed linen and } \\
\text { cleaning the mattress }\end{array}$ & 1226.671889 & 496 & 0.404346105 \\
\hline 12. & $\begin{array}{l}\text { hand over with another room } \\
\text { nurse }\end{array}$ & 3315.162741 & 496 & 0.149615581 \\
\hline 13. & $\begin{array}{l}\text { inputting service reports on the } \\
\text { computer }\end{array}$ & 628.8525248 & 496 & 0.788738186 \\
\hline 14. & Consult with a doctor & 1947.761194 & 496 & 0.254651341 \\
\hline 15. & drop off / pick up the patient & 1100.395257 & 496 & 0.450747126 \\
\hline \multicolumn{4}{|c|}{ Sub total number of Nurse Needs } & 28.37509579 \\
\hline \multicolumn{4}{|c|}{ Establish Leeway Standards } & 0.023775782 \\
\hline \multicolumn{4}{|c|}{ The number of Nurse Needs with the WISN Method } & 28.39887157 \\
\hline
\end{tabular}

From Table. 3 shows the number of nurses implementing the calculation by using the method of WISN is 28 nurses in the inpatient room was a nurse. The calculating nurses' needs are:

$\mathrm{HR}=$ quantity of principal activities + Leeway Standards Workload Standards

While in the Pediatric Room Hospital "X" currently had 24 nurses. Determine the WISN Ratio by dividing the number of nurses available in the room with the required nurses based on the WISN method. 


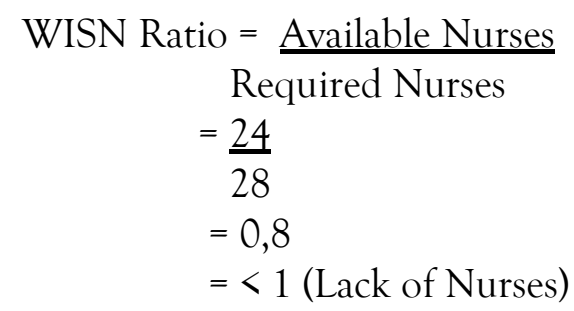

The WISN Ratio results show that there is a lack of nurses in the room.

This is in accordance with the statement which has a WISN ratio of $0.7<1$. It means that the human resources in the unit are not sufficient and not in accordance with the work load (Ekawati, 2018). The WISN findings can be used in different ways to define more appropriate staffing. Although one approach might be to use the average staff requirement as the new staffing, the WISN findings demonstrate that health centers and clinics in hospital Namibia vary widely in their workloads (Mcquide \& Forster, 2013).

In determining the needs of nurses, the proportion between vocational and professional nurses must also be considered. One of nurse's competency improvements is with nurse's career path. If the nurse's career path is evenly distributed and the application of authority is in accordance with hospital standards, it will help reduce the excess workload of nurses. There are still many discrepancies between job description with implementation in the field. The distribution of nurses' career paths in the inpatient room was not evenly distributed. In incompatibility of clinical authorities carried out by Clinical nurse I, II, III (Nugraha Adi Kusumah, Richa Noprianty, 2019), (Pendidikan \& Indonesia, 2019).

There was a real staff shortage of both nurses and nursing assistants in hospital, and the shortage of nursing assistants was twice that of nurses. However, the shortage of nursing staff was in part being relieved by the student nurses from the nurse training school. (Mugisha \& Namaganda, 2008) The statement is also supported by a journal Application of the Workload Indicators of Staffing Need method to predict nursing human resources at a Family Health Service which has result of WISN ration of 0.6 for nurses and 1.0 for nursing technicians/auxiliary nurses. It means that the current number of workers is smaller than the required number of workers (Laus et al., 2016).

The shortage of the required number of workers leads to high workload conditions, which can lead to a decrease in productivity that will trigger job stress and this will impact on patient's safety. The WISN tool is not intended for one-off use. By design, it is hoped that countries or facilities will mainstream the tool into the management processes for health workforce planning and implementation (Firmansyah et al., 2019), (Resources et al., 2015).

\section{CONCLUSION}

The need for nurses based on the Workload Indicator Staff Need Method (WISN) in the Pediatric Ward of the "X" Hospital is 28 nurses; there is 24 staff, with a WISN ratio of 0.8 or less than 1 , which means there is a shortage of nursing staff.

\section{REFERENCE}

Cucu , Hesti Nuraeni, A. M. (2019). Analisis Beban Kerja Perawat di Ruang Rawat Inap Rumah Sakit Gigi Mulut Universitas Padjadjaran Tahun 2018. JSK, 4(4), 164-172. 
Dewi, T., \& Noprianty, R. (2018). Phenomenologi Study: Risk Factors Related to Fall Incidence in Hospitalized Pediatric Patient with Theory Faye G. Abdellah. NurseLine Journal, 3(2), 81. https://doi.org/10.19184/nlj.v3i2.8249

Ekawati, A. (2018). The Analysis of Workload and Need of Nurse With Wisn Method in Inpatient Room in Hospital $X$ in Yogyakarta. 7(April), 69-75. https://doi.org/10.18196/jmmr.7158

Firmansyah, C. S., Noprianty, R., \& Karana, I. (2019). Perilaku Caring Perawat Berdasarkan Teori Jean Watson di Ruang Rawat Inap. Jurnal Kesehatan Vokasional, 4(1), 33-48. https://doi.org/10.22146/jkesvo.40957

Gillies, A. D. (1996). Nursing Management: A system approach (2nd ed.). W.B. SaundersCompany.

Julia, P., Rambe, A. J. M., \& Wahyuni, D. (2014). Analisis Kebutuhan Tenaga Perawat Berdasarkan Beban Kerja dengan Menggunakan Metode Workload Indicator Staff Need (WISN) dan Work Sampling. EJurnal Teknik Industri, 5(2), 22-25.

Kementrian Kesehatan Republik Indonesia. (2010). Keputusan Menteri Kesehatan Repulik Indonesia Nomor: 81/Menkes/SK/I/2004 Tentang Pedoman Penyusunan Perancanaan Sumber Daya Manusia Kesehatan di Tingkat Provinsi, Kabupaten/Kota serta Rumah Sakit.

Laus, A. M., Leal, A. E., Maria, F., Fugulin, T., \& Gaidzinski, R. R. (2016). Application of the Workload Indicators of Staffing Need method to predict nursing human resources at a Family Health Service. https://doi.org/10.1590/1518-8345.1010.2683

Marquis, B. L., \& Huston, C. J. (2010). Kepemimpinan dan Manajemen Keperawatan: Teori $\mathbb{E}$ Aplikasi (4th ed.). EGC.

Mcquide, P. A., \& Forster, N. (2013). Applying the workload indicators of staffing need ( WISN ) method in Namibia: Challenges and implications for human resources for health policy.

Mugisha, J. F., \& Namaganda, G. (2008). Theme One: Human Resources For Health Using The Workload Indicator Of Staffing Needs (Wisn) Methodology To Assess Work Pressure Among The Nursing Staff Of Lacor Hospital. 6(1), 1-15.

Ni Luh Ade Kusuma Ernawati, Nursalam, L. D. (2011). Kebutuhan Riil Tenaga Perawat dengan Metode Workload Indicator Staff Need (WISN). Jurnal Ners, 6(1), 85-92.

Noprianty, R. (2013). Analisis beban kerja tenaga perawat pelaksana berdasarkan karateristik unit pelayanan di RSUD Dr. H. Muhammad rabain. UGM.

Nugraha Adi Kusumah, Richa Noprianty, L. (2019). Evaluasi Pelaksanaan Kompetensi Berdasarkan Jenjang Karir Profesional Perawat. Jurnal Kesehatan Vokasional, 4(2), 93101.

Nursalam. (2015). Manajemen Keperawatan: Aplikasi dalam Praktik Keperawatan Profesional (5th ed.). Salemba Medika.

Pendidikan, J., \& Indonesia, K. (2019). Jenjang Karir Perawat dan Kepuasan Pasien terhadap Kualitas Pelayanan Keperawatan. https://doi.org/10.17509/jpki.v5i2.17404

Resources, H., Observer, H., \& No, S. (2015). Workload indicators of staffing need (wisn): Selected country implementation experiences. 15.

Rusell C. Swansburg. (2004). Pengantar Kepemimpinan $\mathcal{E}$ Manajemen Keperawatan Untuk Perawat Klinis. EGC. 
Samsuzzaman, D. (2013). A study to calculate the nursing staff requirement for the Maternity Ward of Medical College Hospital, Kolkata Applying. 8(3), 1-7.

Sitti Nurjanah, Ambo Sakka, P. (2017). Analisis Beban Kerja Tenaga Perawat di Instalasi Rawat Inap Rumah Sakit Umum Daerah (RSUD) Kota Kendari. Jurnal Ilmiah Mahasiswa Kesehatan Masyarakat (JIMKESMAS), 2(5), 1-11. 